\title{
Factors Affecting Millennial Customers' Savings Intention in Islamic Banks
}

\author{
Nadia Nila Henda Resty and Anas Hidayat
}

\section{ABSTRACT}

\begin{abstract}
One of the intentioning topics in the banking world is the merger of StateOwned Sharia Banks into one name, namely Bank Syariah Indonesia. This encourages researchers to explore further, one of which is in the marketing aspect. This study aims to analyze the factors that affect the intention in saving at Bank Syariah Indonesia for millennials. This research is a quantitative study with data collected through a questionnaire to 250 millennials in Yogyakarta. The analysis in this study uses a structural equation model with Smart PLS software. The results of this study indicate that product knowledge, religiosity and brand image have a significant effect on millennial attitudes towards Bank Syariah Indonesia. This research also finds that subjective attitudes and norms do not have a significant effect on the intention in becoming a customer at Bank Syariah Indonesia.
\end{abstract}

Keywords: Product knowledge, brand image, religiosity, attitudes, subjective norms, Bank Syariah Indonesia.

\author{
Submitted : June 22, 2021 \\ Published : July 15, 2021 \\ ISSN: $2507-1076$ \\ DOI: $10.24018 / \mathrm{ejbmr} .2021 .6 .4 .949$ \\ Nadia Nila Henda Resty \\ Magisters Management Program, Faculty \\ of Business and Economics, Universitas \\ Islam Indonesia, Indonesia. \\ (e-mail: Nayanhr19@gmail.com) \\ Anas Hidayat \\ Magisters Management Program, Faculty \\ of Business and Economics, Universitas \\ Islam Indonesia, Indonesia. \\ (e-mail: anas.hidayat ${ }^{\circledR}$ uii.ac.id)
}

*Corresponding Author

\section{INTRODUCTION}

This study aims to determine the intention in saving by Millennials in Yogyakarta. In analyzing a person's intention, in psychological theory there is a theory, namely Theory Reasoned of Action (TRA), namely the theory proposed by Ajzen \& Fishbein [1]. The Theory of Reasoned Action (TRA) is a theory that focuses on intentions. In the TRA theory, it was found that the Subjective Norm had a significant effect on behavioral intentions [1].

Previous research conducted by Noor et al. [2]. This is done by using the dimensions in the TPB theory which is the development of TPA with its influence on consumers' purchase intentions on online products. The dimensions of the TPB adopted in this research are attitudes, subjective norms, and behavioral control. With reference to this research, this study also adopts dimensions in TPB theory, namely attitudes, subjective norms, which are combined with variables such as product knowledge, brand image, religiosity, and their influence on millennial customer intention.

The variables in this study that are compatible with this study, namely, Attitude refers to a person's inner feelings to indicate whether the individual likes or dislikes something, for example a brand or a product. Lee et al., [3] stated Attitude is a learned tendency to behave in a way that remains pleasant or unpleasant towards a certain object in their theory Ajzen I. \& Fishbein M. [1] found that attitude has a significant effect on one's intentions.

In another study conducted by Lujja \& Omar [4] found that attitude had a positive and significant effect on behavioral intentions to use Islamic banks. Research conducted by Bananuka et al. [5] found that attitude is a mediator between subjective norms and intentions to use Islamic banks. Also mediates Religiosity and Intention to use Islamic Banks. Lujja \& Omar [4] found that subjective norms indirectly influence behavioral intentions (intention to use) to use Islamic banks. Lajuni et al. [6] suggested that if under the influence or social pressure is very significant then, an individual will perform the expected behavior.

Studies with similar results to Lujja \& Omar [4] namely Chau \& Hu, [7]-[9] with studies conducted in Morocco. The three researchers found that the Subjective Norm had no significant effect in testing the intention in using Islamic Banks. most of the previous researchers said that the Subjective Norm was the weakest variable in most of the TRA studies.

Religiosity is one of the factors that influence a person's intention in saving at Islamic Banks (Muhammad). Religiosity itself means a form of devotion to religion. There are 5 elements that influence a person's religiosity, namely ideology, ritualistic, experiential, intellectual, and consequence [10].

Research conducted by Rachmatullah [11] found that religiosity had no effect on customer saving decisions in Islamic banks. However, in a study conducted by Kaawaase [12], the results showed that attitudes, subjective norms, and religiosity had a significant effect on the intention to be loyal to using Islamic banks.

Knowledge of products owned by the public or potential consumers is a factor that can influence someone in deciding to use Islamic banking as their choice. In addition to product 
knowledge, brand image is the most important thing that must be owned by a business entity. Brand Image itself means the consumer perceptions and opinions of a brand as a reflection of consumers' assessments of products, services and various aspects provided by the brand [13]. Bank Syariah Indonesia in terms of Brand Image, maybe most people already have a concept or association in their mind just by hearing the word Islamic Bank is a Bank that runs and manages business activities based on Islamic sharia principles. Islamic banks by type consist of Islamic Commercial Banks and Bank Pembiayaan Rakyat Shariah (BPRS).

Bank Syariah Indonesia (BSI) which has been ratified by the government as of February 1, 2021 by President Joko Widodo, which is expected to be the locomotive of economic development and a source of financing for the economy, bears such a huge burden because the expectations that accompany the presence of Bank Syariah Indonesia are so great. As a financial service, it is very vital for stakeholders (stackholders) to know the factors that influence the preferences of prospective customers in choosing a financial service.

Therefore, based on previous empirical studies and theories related to saving intention, this study will further analyze the effect of product knowledge, religiosity and brand image on millennial attitudes towards Bank Syariah Indonesia. And also, the effect of millennial attitudes and subjective norm on the intention to be a customer in Bank Syariah Indonesia.

\section{THEORETICAL FRAMEWORK}

\section{A. Knowledge about Product}

Knowledge about products or product attributes is an important factor in influencing perceptions, behavior, desires, and decision making by a consumer. Without adequate product knowledge, it is impossible for a consumer to use a product or service. According to [14] suggests that product knowledge is a collection of various kinds of information about products. Eagle \& Dahl [15] emphasize that product knowledge is knowledge of product categories, product terminology, product attributes, and knowledge of product brands.

Islamic banks differ from conventional banks in the context of operational principles and product features provided. The most significant difference in product features is in terms of product names, Islamic Bank contract mechanisms. In Law No. 21 of 2008 it is stated that a Sharia Bank is a Bank that operates based on sharia principles. So that contracts at Islamic banks use sharia contracts such as, Muharabah, Musyarakah, Murabaha, Wadiah, Ijarah, QardulHasan, Istisna. These terms are certainly very foreign to some people. So that a prospective customer certainly needs to have knowledge about Islamic banking products before choosing to use Islamic banks.

H1: Knowledge about product has positive and significant effect on attitude.

\section{B. Brand Image}

Balmer et al. [16] explains that brand image is an interpretation of various accumulated information received by consumers. Kotler [17] interpretation is carried out by a consumer or prospective customer on the collection of information he obtains. The brand image of a product, service or even a business entity can be communicated through a logo, or symbols used by the company to represent the product or the company itself. The logo or symbol displayed by a company or listed in a product not only serves as a differentiator with similar products, but also is a reflection of the quality and vision of a company.

$\mathrm{H} 2$ : Brand image has positive and significant effect on attitude.

\section{Religiosity}

Religiosity has now become the focus of studies, especially in relation to several variables such as sexual behavior [18], mental disorders and intelligence [19], religion as identity [20]. Religiosity according to Ancok \& Suroso [21] is religiosity which includes various dimensions which not only occurs when a person performs ritual behavior (worship) but also when doing other activities that are driven by spiritual power. Islam as a religion not only regulates the relationship between man and his god, but also the relationship between human beings.

H3: Religiosity product has positive and significant effect on attitude.

\section{Attitude}

Attitude is everything related to perception and behavior. According to the large Indonesian dictionary W.J.S. Poerwodarminto's understanding of attitude is an act based on beliefs based on the norms that exist in society and usually religious norms. Elis argues that attitude involves some knowledge of something. However, the most essential aspect of attitude is the feeling or emotion, a tendency towards actions related to knowledge. Social psychologists and personality psychologists have another concept of attitude. That is, attitude is a kind of readiness to react to an object in certain ways [22].

H4: Attitude has positive and significant effect on saving intention.

\section{E. Subjective Norms}

Subjective norm is one of the variables in the theory of planned behavior (TPB) proposed by Ajzen \& Fishben [1] in relation to the intention to predict a person's behavior. Subjective norms are individual perceptions of the expectations of influential people in their lives (significant others) regarding certain behaviors or not. The perception in question is a subjective perception, so it is called a subjective norm. In The Theory of Planed Behavior is influenced by belief. In the theory proposed by Ajzen \& Fishben [1] Subjective norms are a function of individual beliefs obtained on the views of other people towards attitude objects related to individuals (normative belief) [23]. 
H5: Subjective norm has positive and significant effect on saving intention.

\section{RESEARCH METHODS}

This research is a quantitative study with statistical analysis using the structural equation model (SEM) method. The population in this study is the millennial generation who live in the city of Yogyakarta. The millennial generation is the generation born in the $1980-2000$ period. From the population, a sample of 250 respondents was taken by random sampling. Data collection techniques in this study using questionnaires. The data collected in this study were then analyzed using a structural equation model using the SmartPLS software.

Data analysis in this study using path analysis method or Path Analysis using Smart PLS 4.0 software. PLS can be used on any type of data scale (nominal, ordinal, interval, and ratio) and the assumptions are more flexible. PLS is also used to measure the relationship of each indicator to its construct. In addition, in PLS, bootstraping tests can be performed on structural models that are outer models and inner models. The data obtained from the research results were then processed using data analysis techniques, namely Path analysis with the Partial Least Square (PLS) method. PLS according to Ghozali (2014) is a powerful analytical method because it is not based on many assumptions.

\section{DATA ANALYSIS}

\section{A. Validity and Reliability Test}

Validity test in PLS can be done by looking at the value of each loading factor. The loading factor value describes the magnitude of the correlation between each measurement item (an indicator in the questionnaire) and the latent variable (the construct). An indicator item is said to have met convergent validity if the loading factor score on each path (path) between components (latent variables) and manifest variables variable 0.7 .

The results of the validity test showed that all indicators had a value of 0.7 except for the indicator items CM1, CM5, CM6, NM4, NS5, PR2, S2 and S6 so they had to be dropped from the analysis. The results of the outer loading test after invalid indicators are dropped are shown in Table I.

Table I shows that all indicators in this study have a value of 0.7 and can be said to be statistically valid and can be used in research constructs. Fig. 1 is an image that shows the research model as a result of outer loading after all indicators are said to be valid.

Furthermore, the reliability test can be seen from the value of Cronbach's alpha and Composite reliability. A construct can be said to be reliable, if it has Cronbach's alpha value it must be 0.6 and the Composite reliability value must be 0.7 . Composite reliability measures the real reliability value of a variable while Cronbach's alpha measures the lowest value (lower bound) of the reliability of a variable so that the Composite reliability value is always higher than Cronbach's alpha value. Cronbach's alpha and Composite reliability values of each variable in this study are shown in Table II.

\begin{tabular}{|c|c|c|c|c|c|c|}
\hline & $\mathrm{CM}$ & $\mathrm{NM}$ & NS & PR & $\mathrm{R}$ & $\mathrm{S}$ \\
\hline CM2 & 0.81 & & & & & \\
\hline CM3 & 0.86 & & & & & \\
\hline CM4 & 0.86 & & & & & \\
\hline NM1 & & 0.84 & & & & \\
\hline NM2 & & 0.85 & & & & \\
\hline NM3 & & 0.86 & & & & \\
\hline NS1 & & & 0.70 & & & \\
\hline $\mathrm{NS} 2$ & & & 0.82 & & & \\
\hline NS3 & & & 0.85 & & & \\
\hline NS4 & & & 0.79 & & & \\
\hline NS6 & & & 0.76 & & & \\
\hline PR1 & & & & 0.77 & & \\
\hline PR3 & & & & 0.84 & & \\
\hline PR4 & & & & 0.83 & & \\
\hline PR5 & & & & 0.85 & & \\
\hline $\mathrm{R} 1$ & & & & & 0.71 & \\
\hline $\mathrm{R} 2$ & & & & & 0.78 & \\
\hline R3 & & & & & 0.82 & \\
\hline R4 & & & & & 0.84 & \\
\hline R5 & & & & & 0.81 & \\
\hline R6 & & & & & 0.85 & \\
\hline R7 & & & & & 0.79 & \\
\hline R8 & & & & & 0.80 & \\
\hline $\mathrm{S} 1$ & & & & & & 0.71 \\
\hline S3 & & & & & & 0.85 \\
\hline S4 & & & & & & 0.86 \\
\hline S5 & & & & & & 0.84 \\
\hline
\end{tabular}

TABLE II: COMPOSITE RELIABILITY AND CRONBACH'S ALPHA

\begin{tabular}{ccc}
\hline & $\begin{array}{c}\text { Cronbach's } \\
\text { Alpha }\end{array}$ & $\begin{array}{c}\text { Composite } \\
\text { Reliability }\end{array}$ \\
\hline Brand Image & 0.80 & 0.88 \\
Saving Intention & 0.81 & 0.89 \\
Subjective Norms & 0.85 & 0.89 \\
Product Knowledge & 0.85 & 0.90 \\
Religiosity & 0.92 & 0.93 \\
Attitude & 0.83 & 0.89 \\
\hline
\end{tabular}

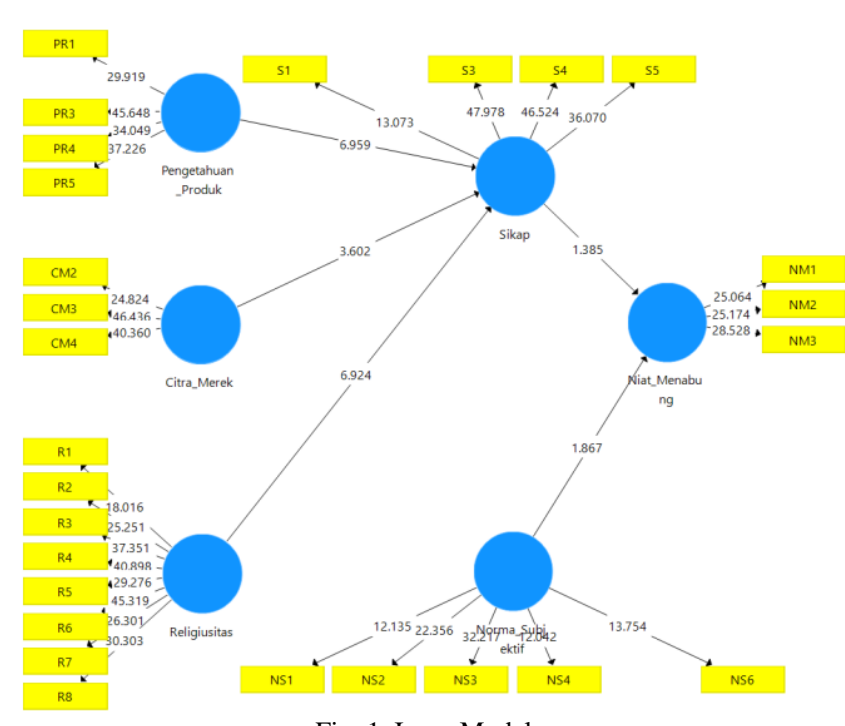

Fig. 1. Inner Model.

Based on Table II, it can be seen that all constructs in this study have Cronbach's alpha value Nilai 0.6 and Composite reliability value 0.7 , it can be said that all constructs are reliable. This can be interpreted that each construct in the research model has internal consistency in the instrument reliability test.

\section{B. Goodness of Fit}

Goodness of fit is a test of compatibility between certain observations (observation frequency) and the frequency obtained based on the expected value (theoretical frequency). 
The goodness of fit value can be known through the following calculation:

$$
\begin{aligned}
& \text { Goodness of fit }=\sqrt{ }\left(\text { AVE X R }{ }^{2}\right) \\
& =\sqrt{ }(0.675 \times 0.41) \\
& =0.526
\end{aligned}
$$

Based on these calculations, it can be seen that the goodness of fit value in this study is 0.526 . GoF has three criteria, namely $\mathrm{GoF}=0.10$ of small value, $\mathrm{GoF}=0.25$ of medium value, $\mathrm{GoF}=0.36$ of large value. The calculation results above show that the combined performance between the measurement model and the structural model has a large value above 0.36 . This explains that the empirical data fits or fits the model (there is no difference between the model and the data, so the data model is said to be fit) [24]. This model can be used to measure millennial interest in saving at Bank Syariah Indonesia.

Furthermore, the analysis of the coefficient of determination is carried out to measure how far the ability of a model to explain the variation of the dependent variable [24]. The value of the coefficient of determination has a range of values between $0-1$ with the criteria the closer to 1 the better. The smaller the value of R-square means that the variation of the dependent variable is very limited, and a value close to 1 (one) means that the independent variable is able to give a greater influence and is able to explain and predict the dependent variable.

\begin{tabular}{ccc}
\multicolumn{3}{c}{ TABLE III: R-SQUARE } \\
\hline & R Square & R Square Adjusted \\
\hline Saving Intention & 0.12 & 0.11 \\
Attitude & 0.71 & 0.71 \\
\hline
\end{tabular}

Based on the R-square value on Table III, the coefficient of determination of each variable is $12 \%$ for the saving intention variable and $71 \%$ for the attitude variable. These results indicate that the coefficient of determination of the saving intention variable is influenced by other variables in this study by $12 \%$, while the remaining $88 \%$ is explained by other variables outside the research model, which means the $\mathrm{R}$-square value is very weak because the independent variable has no effect on saving intention. The coefficient of determination of the attitude variable is $71 \%$ influenced by other variables in this study, while the remaining $29 \%$ is explained by other variables outside the research model, which means that the R-Square value of the attitude variable can be said to be high.

Hypothesis testing is an analysis of the relationship between variables in accordance with the hypothesis formulated in this study. Hypothesis testing is part of the output inner model of the Smart-PLS software. The output of the inner model can be generated through the bootstrapping process and the results of hypothesis testing can be seen in the path coefficient table. The results of hypothesis testing can be seen from the estimated path coefficients that can be evaluated based on the T-statistics and P-Value values. The estimated path coefficient shows the estimated value that describes the relationship between latent variables obtained by the bootstrapping procedure.

The relationship between variables in this study can be said to be significant if it has a T-statistic value greater than 1.96 and a probability value less than 0.05 at a significance level of $5 \%$. While the direction of influence between variables is shown by looking at the positive or negative of the original sample value [24]. The results of hypothesis testing are shown in Table IV and Fig. 1.

TABEL IV: PATH COEFFICIENT

\begin{tabular}{lccc}
\hline \multicolumn{4}{c}{ TABEL IV: PATH COEFFICIENT } \\
& $\begin{array}{c}\text { Original } \\
\text { Sample (O) }\end{array}$ & T Statistics & $\mathrm{P}$ \\
\hline Knowledge -> Attitude & 0.361 & 6.959 & 0.000 \\
Brand Image -> Attitude & 0.184 & 3.602 & 0.000 \\
Religiosity -> Attitude & 0.466 & 6.924 & 0.000 \\
Attitude -> Saving Intention & 0.154 & 1.385 & 0.167 \\
Subjective Norm -> Saving & 0.214 & 1.867 & 0.063 \\
Intention & &
\end{tabular}

Based on the results of the path coefficient test in Table II, it can be concluded that this study has a positive original sample value so that the relationship between variables in this study is a positive relationship. The results of the path test can be used to prove the research hypothesis as follows:

1. Product knowledge has a positive and significant effect on attitudes as evidenced by the original sample value being positive, the $t$-statistic value above 1.96 and the $P$ value below 0.05 . So H1 is supported.

2. Brand Image has a positive and significant effect on attitudes as evidenced by the original sample value being positive, the t-statistic value above 1.96 and the $\mathrm{P}$ Value below 0.05 . So H2 is supported.

3. Religiosity has a positive and significant effect on attitudes as evidenced by the positive value of the original sample, the t-statistic value above 1.96 and the $\mathrm{P}$ value below 0.05 . So H3 is supported.

4. Attitude has a positive and insignificant effect on saving intentions as evidenced by the original sample value being positive, the t-statistic value below 1.96 and the $\mathrm{P}$ Value above 0.05 , so $\mathrm{H} 4$ is not supported.

5. Subjective norms have a positive and insignificant effect on saving intentions as evidenced by the original sample value being positive, the t-statistic value below 1.96 and the $\mathrm{P}$ Value above 0.05 , so that H5 is supported.

6

\section{DISCUSSION}

This study analyzes the relationship between product knowledge, brand image and religiosity on customer attitudes. On the other hand, this study also analyzes the relationship between attitudes and subjective norms on the intention to save at Islamic banks. From these analyzes, 5 hypotheses were drawn up based on the findings of previous researchers. The results of the analysis in this study found that all hypotheses in this study were supported.

The first hypothesis in this study is that product knowledge has a positive and significant effect on customer attitudes. The results of the analysis in this study found that the first hypothesis is supported, so it is proven that if knowledge related to Islamic banking products increases, then customer attitudes regarding saving in Islamic banks increase. These results are supported by several previous studies such as [25], [26]. This study emphasizes the importance of increasing knowledge related to Islamic banking for customers, especially the millennial generation because it can improve attitudes. 
A consumer must first know a product before they like and then choose to use the product. A person's attitude towards a product that is influenced by product knowledge has been proven by research conducted by Puteri [25] where product knowledge has a significant effect on attitudes. Then research conducted by [26] which found that knowledge has a positive and significant effect on attitudes.

Consumers have three forms of knowledge about products, namely knowledge of product attributes, knowledge of both positive and negative benefits of using products, and about product values that can satisfy consumer needs [27]. A potential customer before deciding to use a product or service, usually consumers first know their needs and seek information about what products are suitable for their needs. This condition will help potential consumers have knowledge of the products they need.

The second hypothesis in this study is that brand image has a positive and significant effect on the attitude of millennial customers of Islamic Banks. The results of the analysis in this study indicate that the second hypothesis in this study is supported so that it is proven that if the bank is able to improve the brand image, the attitude of millennial customers in Islamic banks will increase. These results are supported by several previous studies such as [16], [24] which also prove empirically the influence of brand image on attitudes.

The image of a product or business will affect the attitude of a consumer towards the product and the company. Nugroho [29] said that an image is reality. Therefore, if the communication in the field does not match the image of the product or company, people will return to reality. Mismatsh between brand image and communication will affect a person's attitude towards a product or service. Research conducted by Tamaka [30] found that Brand Image has a positive and significant effect on attitudes. Another study conducted by Akbar [28] also found the same result, namely that brand image has a positive and significant effect on attitudes.

The results of the analysis in this study recommend that Islamic bank managers be able to improve brand image. The brand image of a product, service or even a business entity can be communicated through a logo, or symbols used by the company to represent the product or the company itself. The logo or symbol displayed by a company or listed in a product not only serves as a differentiator with similar products, but also is a reflection of the quality and vision of a company. The image of a product or business will affect the attitude of a consumer towards the product and the company.

The third hypothesis in this study is that religiosity has a positive and significant effect on millennial attitudes. The results of the analysis in this study support the third hypothesis and prove that an increase in religiosity for millennials will have an impact on their attitude towards Indonesian Islamic Banks. These results are supported by several previous studies including Rahman [31]-[33] which also proves empirically the influence of religiosity on attitudes.

This study emphasizes the importance of religiosity for millennials in an effort to improve their attitude towards Bank Syariah Indonesia. There have been many studies that use religiosity as a variable and its relationship to a person's attitude. Rahman [31] found an influence between religiosity and attitude. In the study it was found that the level of consumer religiosity affects consumer preferences for halal products. Bone [32] found the same result. Namely, religiosity has a positive influence on consumers' intention to buy halal meat.

Sabar \& Ibrahim [33] found that the majority of youth in Malaysia use halal products due to their religious beliefs. The research mentioned above is in the context of the influence of religiosity on intention in products, not services. Another study conducted by Rachmatullah [11] the result is that religiosity partially does not significantly affect the decision to save in Islamic banks. Research with the same object, namely Islamic banking, was conducted by Kaawaase [12] with the result that attitudes, subjective norms and religiosity have a significant effect on the intention to be loyal to using Islamic banks.

The fourth hypothesis in this study is that attitude has no significant effect on intention in becoming a customer of Bank Syariah Indonesia. The results of the analysis in this study indicate that the fourth hypothesis in this study is not supported because it is proven that millennial attitudes towards Indonesian Islamic Banks are indeed able to have an influence on intention in becoming customers, but the effect is not significant. These results are different from several previous studies by Lujja \& Omar [4], [12] which found that the attitude of being able to have a significant effect on saving intention.

Research conducted by Ajzen \& Fishbein [1] found that subjective attitudes and norms have a significant effect on a person's behavioral intentions. Another study conducted by Lujja \& Omar [4] confirmed the results of research conducted by Ajzen \& Fishbein [1] that attitudes have a significant positive influence on behavioral intentions to use Islamic banking. Subsequent research was conducted by Kaawaase [12] with the results that attitudes, subjective norms and religiosity had a significant effect on the intention to be loyal to using Islamic banks.

Attitude is concerned with whether a person thinks that it is important for them to believe that a certain behavior should be completed. However, the most essential aspect of attitude is the feeling or emotion, a tendency towards actions related to knowledge. Attitude is a person's reaction that appears in response to something, and the reaction that appears is based on knowledge. The reactions that arise are always related to two alternatives, namely like (like) or dislike (dislike). Attitude is a real action and has been done by someone. Intention are factors that are still in the individual and have not been stated in a tangible form.

The fifth hypothesis in this study is that subjective norms have a positive and insignificant effect on millennial intention in becoming customers at Bank Syariah Indonesia. This hypothesis is based on the findings of several previous researchers, namely by Chau \& $\mathrm{Hu}$ [7]-[9]. The results of the analysis in this study support the fifth hypothesis so that it is proven that subjective norms are not the main factor that can significantly influence millennial intention in becoming customers at Bank Syariah Indonesia.

Research conducted by Lujja \& Omar [4] found that subjective norms have no significant effect on a person's intention in using Islamic banks. Lajuni et al. [34] suggests that if under the influence or social pressure is very significant 
then, an individual will perform the expected behavior. Although he may not support doing the behavior. Studies with similar results to Lujja \& Omar [4] namely Chau \& Hu [7]-

[9] with studies conducted in Morocco. The three researchers found that the Subjective Norm had no significant effect in testing the intention in using Islamic Banks. The results of this study confirm most previous studies if the Subjective Norm is the weakest variable in increasing intention in saving.

\section{CONCLUSION}

This study analyzes 6 variables related to marketing at Bank Syariah Indonesia, namely product knowledge, brand image, religiosity, attitude, subjective norms, and intention in being a customer. Of the six variables, it was developed based on the theory and previous research into 5 hypotheses which were analyzed in this study. From the 5 hypotheses analyzed, it was found that the first, second, third, fifth hypothesis were supported, and the fourth hypothesis was not supported.

From the results of the analysis in this study, the authors recommend several implications of the findings to the managers of Indonesian Islamic Banks. Sharia bank managers are advised to pay more attention to and target customers with high product knowledge and religiosity because it has been empirically proven to be able to improve millennial customer attitudes.

The management of Bank Syariah Indonesia should also pay attention that with a good brand image, prospective customers especially from the millennials will have a good attitude towards Bank Syariah Indonesia. A good attitude is a customer's willingness to use, recommend and provide good reviews of Indonesian Islamic Banks. This certainly has many benefits for Indonesian Islamic Banks.

\section{REFERENCES}

[1] Fishbein, M., Jaccard, J., Davidson, A. R., Ajzen, I., \& Loken, B. (1980). Predicting and understanding family planning behaviors. In Understanding attitudes and predicting social behavior. Prentice Hall.

[2] Noor, N. M., Noranee, S., Zakaria, M. F., Unin, N., \& Suaee, M. A. H. M. (2020). Online Shopping: The Influence of Attitude, Subjective Norm and Perceived Behavioral Control on Purchase Intention. ACM International Conference Proceeding Series, February, 33-36.

[3] Lee, S. Y., Hoerr, S. L., Weatherspoon, L., \& Schiffman, R. F. (2008). Nutrition Students Improve Attitudes after a Guided Experiential Assignment with Older Adults. Journal of Nutrition Education and Behavior, 40(5), 279-287. https://doi.org/10.1016/j.jneb.2007.09.01.

[4] Lujja, S., Mohammad, M. O., \& Hassan, R. (2016). Modelling public behavioral intention to adopt Islamic banking in Uganda. International Journal of Islamic and Middle Eastern Finance and Management.

[5] Bananuka, J., Kasera, M., Najjemba, G. M., Musimenta, D., Ssekiziyivu, B., \& Kimuli, S. N. L. (2019). Attitude: mediator of subjective norm, religiosity and intention to adopt Islamic banking. Journal of Islamic Marketing, 11(1), 81-96.

[6] Lajuni, N., Wong, W., Ming, P., Yacob, Y., Ting, H., \& Jausin, A. (2017). International Journal of Economics and Financial Issues Intention to Use Islamic Banking Products and Its Determinants. International Journal of Economics and Financial Issues, 7(1), 329333.

[7] Chau, P. Y. K., \& Hu, P. J. H. (2001). Information technology acceptance by individual professionals: A model comparison approach Decision Sciences, 32(4), 699-719.

[8] William Lewis, R. A. and V. S. (2003). Sources of Influence on Beliefs about Information Technology Use: An Empirical Study of Knowledge Workers. Optics and Photonics News, 27, 657-678.
[9] Olaniyi, O., Management, A. E.-J. of B., \& 2012, undefined. (n.d.) Using Theory of Reasoned Action to Model the Patronization Behaviour of Islamic Banks' Customers in Malaysia. Espace. Curtin. Edu. Au. Retrieved April 9, 2021, from https://espace.curtin.edu.au/handle/20.500.11937/52269.

[10] Robbins, R., Glock, C. Y., \& Stark, R. (1966). Religion and Society in Tension. Sociological Analysis, 27(3), 173.

[11] Rachmatulloh, D. P. (2020). Pengaruh literasi keuangan syariah, religiusitas dan kualitas pelayanan terhadap keputusan menabung di bank syariah: Studi pada generasi milenial di Indonesia (Doctoral dissertation, Universitas Islam Negeri Maulana Malik Ibrahim).

[12] Kaawaase, T. K. (2017). Religiosity and Islamic Banking in Uganda. 13(1), 70-93.

[13] Kotler, P., \& Keller, K. L. (2006). Marketing Management 12e. France: Edition Pearson Education.

[14] Sumarwan, U. (2011). Perilaku konsumen: Teori dan penerapannya dalam pemasaran. Bogor: Ghalia Indonesia.

[15] Eagle, L., \& Dahl, S. (2018). Product placement in old and new media: examining the evidence for concern. Journal of Business Ethics, 147(3), 605-618.

[16] Balmer, J. M., Lin, Z., Chen, W., \& He, X. (2020). The role of corporate brand image for B2B relationships of logistics service providers in China. Journal of Business Research, 117, 850-861.

[17] Kotler, P. (2005). The role played by the broadening of marketing movement in the history of marketing thought. Journal of Public Policy \& Marketing, 24(1), 114-116.

[18] Grinstein, G., \& Levkowitz, H. (Eds.). (2013). Perceptual issues in visualization. Springer Science \& Business Media.

[19] Stempel, C. (2005). Adult participation sports as cultural capital: A test of Bourdieu's theory of the field of sports. International Review for the Sociology of Sport, 40(4), 411-432.

[20] Cousens, L., Barnes, M., \& MacLean, J. (2012). Strategies to increase sport participation in Canada: The role of a coordinated network. International Journal of Sport Management and Marketing, 12(3-4), 198-216.

[21] Ancok, D., Suroso, F. N., \& Ardani, M. S. (2000). Psikologi islami: Solusi islam atas problem-problem psikologi. Pustaka Pelajar.

[22] Adawiyah, W. R. (2015). Pertimbangan, pengetahuan, dan sikap konsumen individu terhadap bank syariah. Jurnal Ekonomi Pembangunan: Kajian Masalah Ekonomi dan Pembangunan, 11(2), 191-201.

[23] Ramdhani, N. (2016). Penyusunan Alat Pengukur Berbasis Theory of Planned Behavior. Buletin Psikologi, 19(2), 55-69. https://doi.org/10.22146/bpsi.11557.

[24] Ghozali, Imam. (2008). Structural Equation Modelling, Edisi II, Universitas. Diponegoro, Semarang.

[25] Putri, P. K. D. (2012). Pengaruh Tingkat Pendidikan, Pengetahuan, Sikap dan Terpaan Iklan Layanan Masyarakat KB Versi Shireen Sungkar dan Teuku Wisnu di TV terhadap Perilaku KB pada Wanita atau Pria dalam Usia Subur. Interaksi: Jurnal Ilmu Komunikasi, 1(1), 46-56. https://doi.org/10.14710/INTERAKSI.1.1.46-56.

[26] Kusuma, I. D., \& Untarini, N. (2014). Pengaruh Pengetahuan Produk Terhadap Niat Beli Dengan Sikap Sebagai Variabel Intervening. Jurnal Ilmu Manajemen, 2, 1573-1583.

[27] Rickwood, C. M., Johnson, L. W., Worthington, S., \& White, L. (2017). Customer intention to save for retirement using a professional financial services planner. Financial Planning Research Journal, 1(1).

[28] Nugraheni, P., \& Widyani, F. N. (2020). A study of intention to save in Islamic banks: the perspective of Muslim students. Journal of Islamic Marketing.

[29] Burhanudin, B. (2020). The effect of Muslims' tendency to regret being customers of conventional banks on their intention to save money in Islamic banks. Journal of Islamic Marketing.

[30] Tamaka, I. (2013). Citra Merek, Ekuitas Merek, dan Kualitas Produk Pengaruhnya Terhadap Dikap Konsumen Pada Produk Daihatsu di PT. Astra International Daihatsu Manado. Journal of Chemical Information and Modeling, 1(9), 1317-1328. http://www.elsevier.com/locate/scp.

[31] Gazali, H. M., Alhabshi, S. M. S. J., \& Adeyemi, A. A. (2019). The Applicability of the Theory of Reasoned Action in Predicting the Intention to Save for Retirement. In Islamic Development Management (pp. 317-328). Springer, Singapore.

[32] Satsios, N., Hadjidakis, S., Sotiropoulos, I., \& Tsounis, N. (2020). Religiosity and Intention towards Saving of a Muslim Minority in Greece. Asian Culture and History, 12(1).

[33] Santoso, A., Tirta, A., \& Ananda, N. A. (2020). Saving Intention for the Sumbawa Regency Community at NTB Syariah Bank

[34] Lajuni, N., Wong, W., Ming, P., Yacob, Y., Ting, H., \& Jausin, A. (2017). International Journal of Economics and Financial Issues Intention to Use Islamic Banking Products and Its Determinants. 
International Journal of Economics and Financial Issues, 7(1), 329333. http:\%0Awww.econjournals.com.

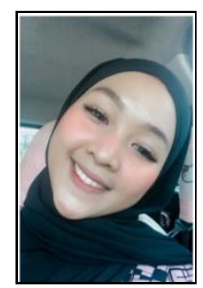

Nadia Nila Henda Resty is a student in Marketing in Magisters Management Program, Faculty of Business and Economics, Universitas Islam Indonesia. She completed bachelor degree in Faculty of Economics Padang State University and continued the Magister degree in Faculty of Business and Economics, Universitas Islam Indonesia and concerned in marketing study.

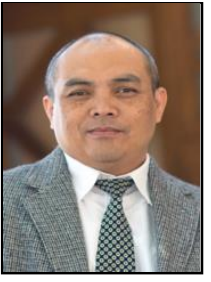

Anas Hidayat is An Associate Professor in Marketing at Magisters Management Program, Faculty of Business and Economics, Universitas Islam Indonesia. is a lecturer of management in Faculty of Economics and Business, Universitas Islam Indonesia. He also completed his Ph.D Degree in Marketing concerning on consumer behavior at Edith Cowan University, Western Australia. Currently $\mathrm{He}$ is still intentioned in consumer behavior since He believes that customers today may have more different views/beliefs due to many issues such as online business issue as well as Syariah/religious issue. Marketing in Service businesses also become his focusing because in global business today, their roles are more and more important. 